\title{
Reconciliation and economic justice in South Africa: The role of the Church and Theology
}

\author{
R T H Dolamo \\ (University of South Africa)
}

\section{ABSTRACT}

Reconciliation and economic justice in South Africa : the role of the Church and Theology

The Church as we understand it, is an alternative community to the State because it has been borne out of the single most important event of the Resurrection of Jesus Christ from the dead (Pannenberg 1972:87). The Church is therefore an institution that does its theology from the christological perspective without doing violence to the other two persons of the Trinity. One important concept that needs to be revisited by the Church through its theology is that of reconciliation with regard to economic justice in South Africa. We have achieved democracy in April 1994, but economic justice will remain an elusive goal, if reconciliation is not related to South Africa's historical socio-economic imbalances. The Church by its nature, must remain a beacon of hope for those who are struggling from the underside and margins of society.

\section{CRY JUSTICE}

The Bible is full of references that put the call for justice in its centre. The books of Leviticus and Deuteronomy as well as the prophets are most important bodies of information among many others. The Sabbatical and the Jubilee Years were meant to redress historical imbalances (Lev 25, Is 61). According to Deuteronomy, for example, the most recurrent and seemingly primary incentive for obedience throughout the book is the resultant blessing of Yahweh on people, land produce, finances and animals in the new land; possessing the new land, inhabiting it and prolonging life in it and retaining it. Disobedience would lead to the very opposite, incurring the wrath of Yahweh. Justice, right and righteousness are very concrete action-based concepts, the opposite being unrighteousness, wickedness, evil, sin or perversion of justice.

The Old Testament grounds justice in God's divine nature and this concept has far-reaching implications for righteous living, righteous judging and righteous reigning. The works expected of the tsadiq, one who practices justice and righteousness, stem from obedience to covenant regulations and result in justice or living a good of upright life, thus preserving the peace and prosperity of the community as a whole. The 
righteousness of the tsadiq is seen in her/his obedience to God's law, in committing no ethical or social sin and particularly in mercy shown towards the poor and needy (Deut 24:13). This then is the ethical aspect of righteousness. In its forensic aspect, righteousness applies to the equality of all, rich or poor, before the Law. The theocratic aspect of righteousness involves the whole nation of Israel living in covenant obedience to Yahweh (Deut 6:25). The New Testament perspective of justice is rooted in the proclamation and inauguration of the reign of God in the Person of Jesus Christ. The gospel writers attest to this centrality of the reign of God especially to the notion of the Jubilee in Luke (Luke 4:18-21). Sloan (1977:166) correctly observes that Luke has intentionally used the Jubilee notion as a metaphorical expression of the eschatological salvation of God. If they observe the injunctions of the Jubilee Year, the disciples are promised the inheritance of the reign of God. Even the Lord's Prayer, especially Luke: "remit us our debts as we ourselves have also remitted them to our debtors" (Luke 11:4), should be understood in the context of the Jubilee Year. Yoder (1972:74) correctly observes that in this prayer, especially in this petition, we are clearly shown that there would be "no grace for him who is not gracious".

According to Crossan (1991:292) the reign of God was not apocalyptic but eschatological. He insists that it was not about the divine intervention to destroy the existing corrupt kingdom and establish a new one, but it was rather a challenge to the existing oppressive kingdom. Crossan (1991:292) further suggests that it was a proposal for an alternative social order in which there would be no distinction between the rich and poor, men and women, and so forth.

A more appropriate modern definition of justice is offered by Nürnberger (1989:12). He defines it as equal rights and equal dignity. According to him, justice is based on equal rights and equal dignity, and justice based on these two concepts implies a social balance. This balance relates to the distribution of power, wealth and status. Nürnberger (1989: $12 \mathrm{ff}$ ) goes further by pointing out that there are three types of justice namely, retributive justice which is aimed at punishing the evil doer, distributive justice that concerns itself with fair and equal distribution of commodities and products among society's different members, and compensatory justice, which is an endeavour to give all members of society a share in the productive process.

Economic justice cannot be fully understood without defining the nature of Economics as a science. Since the area of economics, especially the complexities of the market forces, are beyond the competence of this paper, let it nonetheless suffice to give the following definition by Galbraith (1958:1-10): "Economics is a social science which studies the principles controlling the effective use of a limited means in many alternative applications". The Collins English Dictionary gives us another 
definition, namely, that economics is the system by which the production, distribution, and consumption of goods and services is organised in a country or community, or the ability of a country to generate wealth through business and industry. Economic goods, which are said to be scarce, are the object of the science of economics and are studied to provide the unlimited needs of the society. The means of production to satisfy the society's needs include land, labour, capital and entrepreneurship.

Scientific socialism, on the one hand, has failed in the Soviet Union and it is barely surviving in countries such as China, North Korea and Cuba, and laissez-faire capitalism, on the other, has disappointed us for centuries (Villa-Vicencio 1992:109-224). Economic growth has not been rigorous in socialists countries and the people became poorer and poorer. Capitalist countries have been experiencing economic booms, but also the poor have become poorer and more numerous, and the rich richer and fewer. As the Church, we must agonise about the best possible economic system that would ensure growth and better living conditions for all.

\section{RECONCILIATION}

According to Readers' Digest Oxford, Complete Word Finder, to reconcile means to "make friendly again after an estrangement", or "restore harmony between". Therefore reconciliation means "conciliation, appeasement, propitiation, pacification, placation", among many other synonyms.

Virtually all religions recognise and acknowledge that things are not as they ought to be or supposed to be. As a result, they have devised a myriad of rituals or rites that are aimed at restoring the relationship between their subject (gods) and the adherents (worshippers). These rites usually take the form of sacrifices or cleansing. In some religions, especially the African Traditional Religions and Judaism, sacrificial blood-letting of animals, and sometimes of humans, seems to have been the most common practice of appeasing and pacifying God/gods/spirits to ensure effective reconciliation for peace and prosperity. Implicitly and explicitly, religions usually include both the spiritual and physical aspects in salvation and liberation. Adherents are also expected to contribute towards the creation and enhancement of the communal life in terms of personal and public morality. Righteousness and justice are the responsibility of every individual member of the community or society.

Christians believe that we were once in perfect fellowship with God, but since the fall of the human race from God's glory, according to the myth of the original sin, things have never been the same again (Gen 1-3). Nonetheless, God never gave up on us. God's objective since then has been to draw us back into God's fellowship. The Old Testament is full of examples of the means and ways by which God had attempted to 
reunite himself with us. We Christians believe that God's becoming human in the person of Jesus of Nazareth, a decisive moment was reached. A cosmological possibility arrived by which all people could be reconciled with God. The death of Jesus on the Cross, and His Resurrection, merely confirmed and sealed what God had already achieved through the Incarnation (Mofokeng 1983).

Jesus provided propitiation for our sins. His vicarious death meant that we did not have to suffer for our rebellion against God. God had to say "No" first against sin, in order for God to say "Yes" to sinners' or to confront sin with the "Law" in order to pronounce the "Gospel" to the repentant sinners (Maimela 1984). As justified sinners we are continually being sanctified through the Holy Spirit. Eschatologically, this process will continue until the consummation of the present human history.

\section{THE CHURCH'S CONTRIBUTION}

\subsection{Church and State}

We look back with irresistible pride and deep sense of satisfaction at what we as South Africans have achieved as a nation, politically and economically since the inception of democracy in April 1994. It has been a great challenge for theology to work in the context of the government of national unity's Reconciliation and Development Programme. It was also an opportunity afforded theology to guide the country, both morally and spiritually, as it grappled with the management of the past, the laying down of new foundations and the actual building of the future in the context of the present.

The South African Council of Churches and the Institute for Contextual Theology, among other organisations, have been tireless and fierce opponents of the apartheid government. Many individuals could be singled out, namely Archbishop Desmond Tutu, Rev Frank Chikane, Dr Beyers Naudé, Dr Simon Farisane and Father Smangaliso Mkhatshwa. Presently the church must move from protest to reconstruction. We Christians have to offer a critical and prophetic support for the government. We must support the government in those projects whose main objectives are to improve the quality of life for all South Africans, especially those which give preferential treatment to the poor.

Unfortunately, the dawn of this fragile democracy has meant, for many Christians, the end of the church's prophetic ministry. This prophetic lull is due also to the fact that the church's prophets, who were very vocal during the apartheid era, have been roped in by the government into its myriad of structures. Some are parliamentarians - national

1 This is a typical Barthian theology based primarily on K Barth's Church Dogmatics IV:1-4. 
and provincial - while others are advisers to cabinet ministers. The former South African Council of Churches' general secretary, Frank Chikane has been appointed by President Thabo Mbeki as his special adviser.

While this approach of government to the churches is laudable and indeed commendable, it disempowers the churches in terms of its critical and prophetic ministry vis-a-vis the State. The new emerging theology should guard against (again) collapsing the Church and State into each other.

\subsection{Justice and Reconciliation}

Reconciliation (and peace) cannot be achieved apart from seeking justice. In the past, the concept of reconciliation was used to quell protests that emanated from the oppressed. It has to be redefined in the context of the biblical tradition. The Kairos Theologians (The Kairos Document 1985) clearly expressed that, according to Scriptures, reconciliation does not come cheaply. It cost the life of God's Son for it to be effected. In socio-economic terms, reconciliation will have ramifications for all of us. It should be understood within the context of the Jubilee and Sabbatical years. Restoration, reparation and compensation are key words if justice is to be dispensed and not denied. Reconciliation is the flip side of justice.

Our political transition from the old order to the new one has been characterised by a commitment of the majority of our citizens to reconcile with one another, and the determination of the government to reconstruct and develop the country and its people.

However, reconstruction and development cannot be successfully undertaken and reconciliation effected without adequately addressing the issues of economic justice. What will happen to those people who had been dispossessed of their land when the country's Constitution guarantees land rights to those who have, over the centuries, acquired it through colonial conquests and theft? Where will the government get the money from to buy the privately owned land when it has inherited from the apartheid government a debt of about R350 billion? How are we going to maintain the bloated civil service which has been inherited from the past when one of the negotiation agreements specifically guarantees jobs for even civil servants for whom the government has no use? Where is this impoverished government going to get the money to pay out retirement and retrenchment packages to those civil servants who have been encouraged to take "golden handshakes", some of them in their mid-forties?

With the majority of our people still unsheltered and unemployed, how are we going to deal with the problems of our Rand's poor performance against the world's major currencies, the unsatisfactory growth rate and the high interest rates? How are we to deal effectively with vio- 
lence, crime and drug trafficking when law enforcement agents' complicity is surely not just a work of a few rotten apples? Who stands to benefit from the government's June 1996 macro-economic strategy known as GEAR? ${ }^{2}$ Is it the government, big business, union leaders or the historically disadvantage people? How will our close and sometimes uncritical fraternisation with the World Bank, the International Monetary Fund and the World Trade Organisation help when their structural adjustment programmes have driven some African countries deeper and deeper into debt, Zimbabwe and Zambia being the latest victims?

\section{RECOMMENDATIONS}

What would be the way forward in addressing the issues raised? A few modest suggestions should suffice:

- The international community should seriously be urged to write off the apartheid debt for at least three reasons. Theologically, this is one of the requirements for the people of God of the Jubilee (Lev 25, Is 61:1-2) declared every fiftieth year. Jesus Christ emphasised the importance of the Jubilee in his first sermon (Luke 4:18-20). Morally, the money lent by the international community should be regarded as blood money since most of it had been used to service the "total onslaught" policy of the apartheid government. At his consecration and enthronement as Archbishop and Metropolitan of the Anglican Church in South Africa on 14 September 1996, the Most Reverend Njongonkulu Ndungane called upon the world community to write off South Africa's debt estimated at R350 billion. Pope John Paul II has declared the year 2000 as a global Jubilee.

- Land which was seized and grabbed by force and through immoral means, especially where such land has not been developed, must be returned without charge to its original owners and without compensation to its present owners.

- South Africa's workforce is paying heavily in terms of tax laws. There is Pay-As-You-Earn of $45 \%$, VAT of $14 \%$, toll road fees, petrol levy and so on, and fringe benefits, even retirement annuities, are being heavily taxed. We do not question that it is our responsibility as citizens to support our democratic government (Rom 13). But what we would like to see happening with our money as taxpayers is

\footnotetext{
${ }^{2}$ GEAR is an acronym for the government's economic policy. It incorporates dangerous concepts such as privatisation of state assets and rationalisation of the country's workforce. It is therefore ironic that it is called The Growth, Employment and Redistribution Policy.
} 
for it to be used to alleviate hardships suffered by the socio-economically marginalised by providing services such as houses and jobs, rather than have the money spent inconsiderately on consultants and commissioners.

- Law enforcement agents who are implicated in syndicates of crime, violence and drug trafficking, regardless of how indirectly or remotely, must be dealt with very harshly. There cannot be mitigating factors in their favour, not even the excuse that they are overworked and underpaid.

- The macro-economic strategy needs closer clinical scrutiny and rigorous interrogation. The self-serving interests of the world's financial institutions and multi-nationals should be exposed. Nowhere in the world has wholesale privatisation of state assets benefited the poor in any fundamental and meaningful form. Although scientific socialism has not succeeded in other countries, laissez-faire capitalism within which privatisation is embedded, has over the years made the poor poorer and more numerous and the rich richer and fewer. Market forces need to be tamed and given a human face.

- The church, theology and religion, in general, should raise the economic plight of the majority of South Africans to the status of a confession. Status confessionis will help, theologically, to declare economic exploitation and impoverishment of the people a sin and a heresy and also anthropologically as a crime against humanity.

\section{CONCLUSION}

Theology means liberation. Whether we talk theology in the area of politics, economics, culture, religion and development, we talk liberation. For the Church and theology, God has accomplished and perfected this project in Jesus Christ.

\section{Consulted literature}

Barth, K 1956, 1958, 1961, 1962.Church Dogmatics IV:1-4. Edinburgh: T \& T Clarke.

Collins English Dictionary.

Crossan, J D 1991. The Historical Jesus: the life of a Mediterranean Jewish peasant. Edinburgh: T \& T Clark.

Galbraith 1985. The Kairos Document: challenge to the church: a theological comment on the political crisis in South Africa. Braamfontein: Skotaville.

Maimela, S S 1984. God's Creative Activity Through the Law: a constructive statement towards a theology of social transformation. Pretoria: University of South Africa. 
Mofokeng, T A 1983. The Crucified Among Cross-bearers: towards a black Christology. Kampen: J H Kok.

Nürnberger, K, Tooke J \& Domeris W (eds) 1989. Conflict and the Quest for Justice. Pietermaritzburg: Encounter Publications.

Pannenberg, W 1972. The Apostles ' Creed in the light of today's questions. London: SCM Press.

Sloan, R B 1977. The Favourable Year of the Lord. Austin.

Villa-Vicencio, C 1992. A Theology of Reconstruction: nationbuilding and Human Rights. New York: Cambridge University Press.

Yoder, J H 1972. The Politics of Jesus, Grand Rapids. 